aleurone and purple pericarpin spring wheat (Triticum aestivum L.). J. Cereal Sci. 2009. V. 50. P. 113-120.

7. Lamy S., Blanchette M., Michaud-Levesque J., Lafleur R., Durocher Y., Moghrabi A., Barrette S., Gingras D. \& Beliveau R. Delphinidin, a dietary anthocyanidin, inhibits vascular endothelial growth factor receptor-2 phosphorylation. Carcinogenesis. 2006. № 27. P. 989-996.

8. Nandy S., Chen Q., Sun Sh., Ahmad F., Graf R. \& Kereliuk G. Nutritional analyses and their inheritance properties in colored wheat seed lines from different origins using near-infrared spectroscopy. Amer. J. Plant. Sci. Biotechnol. 2008. 2(2). P. 74-79.

9. Ермаков А.И. Методы биохимического исследования растений. М.: Колос, 1982. С. 128-139

DOI https://doi.org/10.30525/978-9934-26-111-4-57

\title{
ЗНАЧЕННЯ МІКРОБНИХ ПРЕПАРАТІВ У РОЗВИТКУ СТАЛОГО СІЛЬСЬКОГО ГОСПОДАРСТВА
}

\author{
Шевченко Л. А. \\ кандидат сільськогосподарських наук, \\ доцент кафедри аграних технологій та лісового господарства \\ Національний університет «Чернігівська політехніка» \\ Рябуха Г. I. \\ кандидат економічних наук, \\ дочент кафедри туризму \\ Національний університет «Чернісівська політехніка» \\ Бондар I. М. \\ старший викладач кафедри аграних технологій та лісового \\ господарства \\ Національний університет «Чернігівська політехніка» \\ м. Чернігів, Украӥна
}

\begin{abstract}
Сьогодні більшість агровиробників погодяться, що одним із сучасних i важливих агротехнічних заходів для підвищення продуктивності сільськогосподарських культур $€$ застосування мікробних препаратів створених на основі грунтових мікроорганізмів, що стимулюють ріст і розвиток рослин. Серед переваг даних
\end{abstract}


препаратів, в першу чергу, є їх екологічна безпечність, окрім того, вони сприяють інтенсифікації фізіолого-біохімічних процесів у рослин, підвищують їхню стійкість до захворювань та позитивно впливають на стан мікробних угруповань грунтів [1].

Науковці більшості країн світу постійно займаються пошуком ефективних мікроорганізмів 3 комплексом позитивних властивостей $\mathrm{i}$ на їх основі розробляють біопрепарати. На сьогодні вже створено велику кількість біологічних препаратів - регуляторів росту і розвитку рослин, які містять збалансований набір фіторегуляторів, біологічно активних речовин, мікроелементів та здійснюють вплив на ростові, коренеутворюючі і метаболічні процеси сільськогосподарських культур, підвищують стійкість до біо-і абіотичниих факторів, збільшують урожайність насіння [2].

Серед унікальних властивостей мікробних препаратів $є$ здатність мікроорганізмів (біоагентів препаратів), на основі яких вони створені, фіксувати азот атмосфери, трансформувати фосфати грунту, продукувати амінокислоти, рістактивуючі сполуки та речовини антибіотичної природи, що стримують розвиток фітопатогенів. Їх дія має пролонгований характер, чого не зможе забезпечити жоден 3 синтетичних препаратів.

Якщо більш детально зупинитися на мікробіологічних аспектах, то серед перспективних біоагентів таких препаратів є мікроорганізми, які стимулюють ріст рослин Plant Growth Promoting (PGP), представники родів Azospirillum, Bacillus, Enterobacter, Gluconacetobacter, Paenibacillus, Pseudomonas, Rhizobium, Azotobacter, Agrobacterium. Окрім здатності синтезувати комплекс біологічно активних речовин вони мають володіють високою колонізуючою здатністю по відношенню до кореневої системи рослин. Сприятливий вплив на ріст рослин показано для багатьох видів і штамів бактерій, виділених не тільки з ризосфери, а і $з$ поверхні листя рослин [3; 4].

Перелік біотехнологічних продуктів включає препарати, створені на основі вільноіснуючих, асоціативних, симбіотрофних азотфіксувальних, фосфатмобілізувальних мікроорганізмів, а також препарати бінарної дії. Серед провідних наукових установ України, які займаються розробкою мікробних препаратів є Інститут мікробіології і вірусології ім. Д.К. Заболотного НАН, Інститут сільськогосподарської мікробіології та агропромислового виробництва НААН, Інститут агроекології і біотехнології НААН.

Питання біопестицидів менш досліджене на теренах нашої країни, але $\epsilon$ певні напрацювання у зарубіжних науковців. Токсичний вплив хімічних пестицидів на живі організми, їх акумуляція та забруднюючий ефект на довкілля спонукає до пошуку альтернативних екологічно безпечних препаратів. Сучасні біопестициди включають біофунгіциди 
(Trichoderma), біогербіциди (Phytopthora) та біоінсектициди (Bacillus thuringiensis, B. sphaericus), які $\epsilon$ кращими за звичайні пестициди завдяки біорозкладаному характеру, високій ефективності, цільовій специфіці та меншому екологічному ризику [5].

Зі зростанням глобальної екологічної свідомості, дослідження i розробки в області застосування біопестицидів значно знижують забруднення навколишнього середовища, викликане хімічними синтетичними препаратами, і сприяють сталому розвитку сільського господарства.

Окремо варто зазначити, що використання мікробних препаратів у землеробстві сприяє не лише підвищенню продуктивності рослин i якості отриманої продукції, але й створює високу концентрацію корисних форм мікроорганізмів у зоні кореня рослин (ризосфері), що позитивно позначається на проходженні окремих біологічних процесів у грунті. Мікробні інокулянти складаються 3 активних штамів мікроорганізмів, які прямо або опосередковано стимулюють мікробну активність i, отже, підвищують рухливість поживних речовин у грунті [6].

Грунтові мікроорганізми та їх продукти неминуче відіграють значну роль у сталому розвитку сільського господарства. Окрім того, вони $\epsilon$ кращою альтернативою подолання серйозних екологічних проблем, які виникають в результаті звичайних хімічних методів.

Таким чином, правильне застосування бактеріальних препаратів на основі рістстимулюючих ризо бактерій, як елементу екологічного землеробства в технології вирощування різних сільськогосподарських культур дозволяє значно зменшити хімічне навантаження на екосистеми в результаті зменшення кількості внесених мінеральних удобрень і хімічного захисту рослин, та призводить до підвищення урожайності i покращення якості екологічно чистої сільськогосподарської продукції [7].

Завдання сталого сільського господарства у всьому світі набагато більш імовірно буде досягнуто завдяки широкому використанню біопрепаратів, а не хімічно синтезованих засобів. Однак для реалізації цієї мети важливо, щоб механізми, які використовувають PGPB, були більш ретельно вивчені та зрозумілі, що дозволило б працівникам сільського господарства повністю використати потенціал цих мікробів. Нинішній стан наших знань щодо фундаментальних механізмів дії PGPB активно обговорюється у багатьох наукових працях.

\section{Література:}

1. Мікробні препарати у землеробстві. Теорія i практика: монографія / [В.В. Волкогон, О.В. Надкернична, Т.М. Ковалевська та ін.]; за ред. В.В. Волкогона. К.: Аграрна наука, 2006. 312 с. 
2. Биопрепараты в сельском хозяйстве. Методология и практика применения микроорганизмов в растениеводстве и кормопроизводстве / Под ред. И.А. Тихоновича, Ю.В. Круглова. М., 2005. 154 с.

3. KapulnikY. Plant growth promotion by rhizosphere bacteria. Plant Root: the hidden half. Edited by Waisel Y., Eshel A., Kafkafi U. Marcel Dekker Ink. New York, Basel, Hong Kong. 1996. P. 769-780.

4. Муродова С.С., Давранов К.Д. Комплексные микробные препараты. Применение в сельскохозяйственной практике. Biotechnologia Acta. 2014. V. 7, No 6. C. 92-101.

5. Singh R., Kumar M., Mittal A., Kumar M. P. Microbial metabolites in nutrition, healthcare and agriculture. Biotech. 2017. V.7. P. 15. doi.org/10.1007/s13205-016-0586-4

6. Андреюк К.І., Іутинська Г.О., Антипчук А.Ф. Функціонування мікробних ценозів грунту в умовах антропогенного навантаження. К.: Обереги, 2001. 240 с.

7. Курдиш I.К. Інтродукція мікроорганізмів у агроекосистеми. К.: Наукова думка, 2010. 255 с.

DOI https://doi.org/10.30525/978-9934-26-111-4-58

\title{
ВИКОРИСТАННЯ БІОПРЕПАРАТІВ В АГРОЦЕНОЗАХ ЛЬОНУ ОЛІЙНОГО
}

\author{
Шувар А. М. \\ кандидати сільськогосподарських наук, \\ завідувач відділу технологій в рослинництві
}

Інститут сільського господарства Карпатського регіону

Національної академії аграрних наук України

\section{Тимчишин О. Ф.}

кандидати сільськогосподарських наук, стариий науковий співробітник відділу технологій в рослинництві Інститут сільського господарства Карпатського регіону Національної академії аграрних наук України м. Львів, Украӥна

Завдяки своїм унікальним властивостям, особливо екологічній чистоті, попит на продукцію льону олійного й продукти його переробки зростає не тільки на внутрішньому ринку України, а й в провідних промислово розвинутих країнах світу [1]. Враховуючи 